\title{
The effect of magnetized seawater on physiological and biochemical properties of different rice cultivars
}

\author{
EKRIS SUTIYANTI, DIAH RACHMAWATI ${ }^{\vee}$ \\ Laboratory of Plant Physiology, Department of Tropical Biology, Faculty of Biology, Universitas Gadjah Mada. Jl. Teknika Selatan, Sekip Utara, Sleman \\ 55281, Yogyakarta, Indonesia. Tel. +62-274-580839, ’email: drachmawati@ugm.ac.id \\ Manuscript received: 20 March 2021. Revision accepted: 8 May 2021.
}

\begin{abstract}
Sutiyanti E, Rachmawati D. 2021. The effect of magnetized seawater on physiological and biochemical properties of different rice cultivars. Biodiversitas 22: 3083-3091. Seawater is an alternative source to overcome the reduced availability of freshwater in agricultural practices. However, seawater cannot be used directly because it has high salinity that causes various disturbances in plant growth and development. Magnetic field treatment can be used for seawater desalination. The objective of this study was to analyze the potential of magnetized seawater for agricultural irrigation by observing the effect of magnetized seawater on physiological and biochemical properties of different rice cultivars. This research was conducted in a Completely Randomized Design (CRD) with 3 research factors, which were 2 rice cultivars (IR 64 and Inpari 35), 2 levels of salinity ( 0 and $10 \mathrm{dS} \mathrm{m}^{-1}$ ), and 4 types of magnetic treatment ( 0 untreated with magnetic device, 1, 2 and 3 cycles treated with magnetic device). Variables including plant growth (plant height, fresh weight and dry weight), physiological characters (chlorophyll content, carotenoid content, membrane stability index, relative water content, proline content) and biochemical properties (superoxide dismutase, malondialdehyde, $\mathrm{H}_{2} \mathrm{O}_{2}$ and anthocyanin content) were observed. Magnetized seawater 3 cycles enhanced growth, physiology and biochemical parameters of IR 64 and Inpari 35 in 0 and $10 \mathrm{dS} \mathrm{m}^{-1}$ level salinity with decreasing level salinity of water to minimize effect of salinity. The effect of magnetized seawater treatment is more visible to increase the growth of IR 64 rice plants.
\end{abstract}

Keywords: Inpari 35, IR 64, magnetized water, rice, seawater

\section{INTRODUCTION}

Available freshwater on earth is less than $1 \%$ which $70 \%$ of it is used for agricultural sector (IWCA 2018) and the increasing population causes a decrease in freshwater availability. An alternative that can be used to overcome the lack of freshwater availability in the agricultural sector is by replacing freshwater with another source of water like seawater (Yermiyahu et al. 2007). However, the salinity of seawater in Java generally ranges from 30-35 \%o (Bahiyah et al. 2019). The range of surface temperature in seawater is between $25^{\circ} \mathrm{C}-31^{\circ} \mathrm{C}$ with the $\mathrm{pH}$ ranges from 7.5 to 8.5 (Hamuna et al. 2018).

Seawater is the largest source of water on earth, i.e., $97 \%$. Seawater contains nutrients, trace elements, and microorganisms that are beneficial for plants (Atzori et al. 2019). But, seawater has high salinity levels cause toxicity to plants. High salinity level can affect the absorption and assimilation of minerals, enzyme activity, photosynthesis, protein expression, and hormone metabolism in plants. These result in reduced leaf area, necrosis, abrasion, disruption of the ionic balance which leads to decreased water content and oxidation damage due to the accumulation of reactive oxygen species (ROS) (Ahanger and Agarwal 2017). Salinity stress in plants affects the absorption and metabolism of essential elements such as $\mathrm{N}$, $\mathrm{P}, \mathrm{K}, \mathrm{S}$, and $\mathrm{Ca}$ leading to changes in photosynthetic efficiency and salinity tolerance mechanisms. Plants carry out tolerance mechanisms by regulating the antioxidant system, osmolytes, and accumulation of secondary metabolites. The use of magnetized water can be used to reduce the salinity of water. Based on this, the use of conjugative seawater with fresh water can be used as an alternative for irrigation water in the agricultural sector $(\mathrm{Li}$ et al. 2019).

Magnetized water is water that is treated with a magnetic field or magnetic water device. Liu et al (2019) reported that giving magnetized water treatment affects soil $\mathrm{pH}$ and increases the availability of nutrients $(\mathrm{Ca}, \mathrm{Mg}, \mathrm{P}$, and $\mathrm{Na}$ ) in the soil. Irrigation with magnetized water is useful to maintain the homeostasis of various salt ions by lowering the $\mathrm{Na}^{+}$ion content, increasing the $\mathrm{Ca}^{2+}$ content and the $\mathrm{K}^{+} / \mathrm{Na}^{+}$ratio causing increased adaptation of plants to environments with salinity (Dhawi 2013). Therefore, the salinity of seawater can be reduced using magnetized water which can then be used in the agricultural sector. According to Ali et al (2014), magnetized water decreases the hydration of salt ions, increases the mobility of nutrients in the soil, improves the effectiveness of fertilizers, and increases the availability and absorption of $\mathrm{N}, \mathrm{P}, \mathrm{K}, \mathrm{Fe}$, and $\mathrm{Zn}$ in plants. Alikamanoglu and Sen (2011) also reported that magnetized water increases soil microbial content and plant resistance to unfavorable environments. Therefore, magnetic treatment for irrigation water could be one of the encouraging ways in the future to enhance agricultural production in response to climate change (Abobatta 2019).

Rice is the largest staple food commodity in Indonesia. Rice productivity decreases due to problems in the planting process, such as drought and salinity stress. Symptoms of 
rice exposed by salinity stress include stunted growth, reduced tillers, whitish leaf tips, and chlorosis. Salinity poisoning also affects the electrical conductivity (EC) value of 6-10 $\mathrm{dS} \mathrm{m}^{-1}$ which causes a decrease of grain yield up to $50 \%$ and rice is classified as a plant with low tolerance against salinity stress (Brinkman and Singh 1982).

The government is encouraging the use of new technologies to increase rice productivity by using superior rice cultivation, proper fertilization, improved farming methods, pests and disease control, and regular irrigation (Taslim et al. 2010). The use of suitable and adaptive superior cultivars can be an alternative for rice production in facing the current climate change. Superior variety seeds have a high level of purity, high growth percentage and high yield potential in certain growing environments so that they can take advantage of local natural resource potentials and usually have higher productivity than widely adapted cultivars (Prayoga et al. 2018). 'IR64' and Inpari 35 are superior rice cultivars that have different characteristics concerning salinity tolerance. Inpari 35 is a salt-tolerant cultivar whereas 'IR64' is a salt-susceptible rice cultivar (Suprihatno et al. 2009).

In response to the decreasing availability of freshwater, alternative sources of water for agricultural irrigation are required, one of which is by analyzing the potential of seawater as irrigation water. Plant response to salinity and various constituent ions in the soil solution and irrigation waters varies widely among plant species. Salt tolerance data may be used to select crops with the highest potential for agronomic production with high saline waters. Soil, water, and climatic factors affect the plant's capability to tolerate soluble salts in the root medium. Plant response to salt stress also changes during growth and development. Recent research showed that cereal crops are sensitive to salt stress especially during the vegetative and early reproductive stages. Growth responses of several crops during sensitive stages of growth and the specific yield components that are affected by salt stress are being quantified. This study aims to analyze the effect of magnetized seawater on physiological and biochemical properties of two different rice cultivars, IR 64 and Inpari 35.

\section{MATERIALS AND METHODS}

\section{Experimental design and treatment}

The experiment was conducted using a Completely Randomized Design (CRD) with three factors, namely cultivars, seawater salinity levels and magnetic water treatment. The cultivars used were 'IR64' and Inpari 35. Salinity level 0 (freshwater) and Ec $10 \mathrm{dS} \mathrm{m}{ }^{-1}$ (conjugative seawater with freshwater) was used as salinity treatment. Magnetized seawater treatments were M0: without treated with magnetic device, M1: 1 cycle, M2:2 cycles, and M3: 3 cycles treated with magnetic device). The JOTO valve and pump China was used as magnetic device. Seawater was obtained from Porok beach, Gunung Kidul Regency, Yogyakarta, Indonesia. Seawater analysis was conducted to determine the macronutrient and micronutrient content, $\mathrm{pH}$, and salinity.

Rice seeds 'IR64' and Inpari 35 were collected from Indonesian Center for Rice Research (ICRC), Indonesia. Seeds were dried under sunlight for a day, then sterilized with ethanol $70 \%$ for 5 minutes and $0,2 \% \mathrm{HgCl}_{4}$ for 2 minutes, then rinsed with sterile aquadest. The seeds then germinated into pots containing $3 \mathrm{~kg}$ of loamy sand soils. In order to obtain magnetized water, both freshwater and conjugative water with salinity level of $10 \mathrm{dS} \mathrm{m}^{-1}$ flowed through a magnetic device $(0,1,2,3$ cycles). Magnetized seawater treatment was given on $14^{\text {th }}$ to $55^{\text {th }}$ day after planting (DAP). The magnetized water was used directly by pouring into the plants. The plants are watered once in two days with $200 \mathrm{~mL}$ of magnetized water for 41days.

The plant growth variable, i.e., plant height was observed once a week for 8 weeks. The plant fresh and dry weight were observed at 25 and 55 DAP. The physiological variables such as level of chlorophyll a, b, carotenoids, membrane stability index, relative water content, proline content, and biochemical properties such as level of anthocyanins, malondialdehyde, superoxide dismutase, and $\mathrm{H}_{2} \mathrm{O}_{2}$ were carried out at 25 and 55 DAP.

\section{Growth analysis}

Plant height was measured every week for each plant in each treatment. In addition, the environmental parameters such as soil moisture and soil $\mathrm{pH}$ were also measured once a week until the end of the treatment at 55 DAP. Plant biomass measurements were carried out by weighing the plant fresh and dry weight at 25 and 55 DAP. Dry weight was measured by drying the samples in an oven, then weighing them until it reaches a constant weight.

\section{Physiological characters analysis}

Analysis of chlorophyll and carotenoid content refers to Yoshida et al. (1976) with a modification. Thirty mg fresh weight of leaf was crushed using liquid nitrogen into a fine powder. The leaf extracts were added with $3 \mathrm{~mL}$ of $80 \%$ acetone and then centrifuged. The absorbance of supernatant was measured at a wavelength $(\lambda)$ of 663,645 , and $470 \mathrm{~nm}$ using a spectrophotometer (GENESYS $10 \mathrm{UV}$ Scanning, Thermo Fisher Scientific). Chlorophyll and carotenoid content were calculated by following equation:

$$
\begin{aligned}
& \text { Ch a }\left(\mathrm{mg} \mathrm{L}^{-1}\right)=(12.7 \times \mathrm{A} 663)-(2.69 \times \mathrm{A} 645) \\
& \text { Ch b }\left(\mathrm{mg} \mathrm{L}^{-1}\right)=(22.9 \times \mathrm{A} 645)-(4.68 \times \mathrm{A} 663) \\
& \text { Ch total }\left(\mathrm{mg} \mathrm{L}^{-1}\right)=(20.2 \times \mathrm{A} 645)+(8.02 \times \mathrm{A} 663) \\
& \text { Carotenoid }\left(\mathrm{mg} \mathrm{L}^{-1}\right)=((1000 \mathrm{~A} 470)-3.27(\mathrm{Ch} \mathrm{a})- \\
& 104(\mathrm{Ch} \mathrm{b})) / 227
\end{aligned}
$$

Conversion $\left(\mathrm{mg} \mathrm{g}^{-1}\right)=(1 / 100 \mathrm{x}$ total chlorophyll content)/ FW sample

Membrane Stability Index (MSI) measured by the electrolyte leakage technique that is used as tolerance index for abiotic stresses according to the method described by Swapna and Korukkanvilakath (2017) were carried out at 25 and 55 days after planting (DAP). Leaf samples were taken $100 \mathrm{mg}$ (without midrib) and cut to a size of \pm 5 
$\mathrm{mm}^{2}$. The leaves were put into a tube containing $100 \mathrm{~mL}$ dd $\mathrm{H} 2 \mathrm{O}$ and incubated for \pm 20 hours in the room with temperature and constant lighting. The initial conductivity value (EC1) was measured using an EC meter. The tubes were then heated in boiling water $\left(100^{\circ} \mathrm{C}\right)$ for 30 minutes and then cooled to $25^{\circ} \mathrm{C}$ for 15 minutes. The final conductivity value (EC2) was measured with an EC meter. Electrolyte leakage percentage was calculated by the following formula:

$$
\mathrm{EL}=(\mathrm{EC} 1) /(\mathrm{EC} 2) \times 100
$$

The membrane stability index value is then calculated by the following formula:

$$
\mathrm{MSI}=1-(\mathrm{EC} 1) /(\mathrm{EC} 2) \times 100
$$

Relative water content (RWC) is an important indicator of water status in plants and it reflects water supply and transpiration rate of leaf tissue (Lugojan and Ciulca 2011). Relative water content was measured at 25 and 55 DAP. Leaf (flag leaf) samples were taken $\pm 5 \times 2 \mathrm{~cm}^{2}$ and weighed to record fresh weight (FW). Then, samples were immersed in $\mathrm{ddH} 2 \mathrm{O}$ for 24 hours under constant lighting to obtain maximum turgidity (TW). Samples were heated for 72 hours at $65^{\circ} \mathrm{C}$. After that, the sample was weighed for dry weight (DW) measurement. Relative water content was calculated by following equation:

\section{$\mathrm{RWC}=(\mathrm{FW}-\mathrm{DW}) /(\mathrm{TW}-\mathrm{DW}) \times 100$}

Proline content was determined based on the method of Bates et al. (1973) at 25 DAP and at the maximum vegetative age 55 DAP. $0.25 \mathrm{~g}$ of leaf samples were frozen with liquid nitrogen and mashed, then homogenized with 5 $\mathrm{mL}$ of $3 \%$ sulfosalicylic acid. The solution was then filtered with Whatman paper No. 1 and the filtrate was taken $1 \mathrm{~mL}$ and reacted with a solution of ninhydrin acid and glacial acetic acid (1: 1: 1). The solution was then heated using a water bath at $100^{\circ} \mathrm{C}$ for 60 minutes and then put into the icebox and cooled for \pm 5 minutes. The filtrate was mixed with $2 \mathrm{~mL}$ of toluene and homogenized with a stirrer to form 2 separate layers. Red toluene-containing proline was taken using a pipette and put into a cuvette. The absorbance was measured using a spectrophotometer with a wavelength of $520 \mathrm{~nm}$. Proline content was calculated by following equation:

Proline $\left(\mu \mathrm{g} \mu \mathrm{mol}^{-1}\right)=$ [proline $\left(\mathrm{mg} \mathrm{L}^{-1}\right) \times \mathrm{mL}$ toluene /115.13 / FW sample.

\section{Biochemical characters analysis}

Oxidative enzyme activity analysis was carried out to determine plant oxidative defense systems through enzymatic regulation of plants in response to oxidative stress. Measurement of Superoxide Dismutase (SOD) content was carried out after the rice was 25 DAP and after the rice reached its maximum vegetative age (55 DAP) (Sitinjak and Idwar 2015) using the method described by Marklund and Marklund (1974). Fresh leaf samples (0.2 g) were frozen with liquid nitrogen and mashed, then homogenized with $0.01 \mathrm{M}$ phosphate buffer ( $\mathrm{pH} 7.0$ ), EDTA $1 \mathrm{mM}$ and PVP 1\%, then centrifuged at 15,000 rpm for 20 minutes at temperature $4^{\circ} \mathrm{C}$. After centrifugation, the supernatant was removed and used as crude enzyme extract. The reaction mixture was prepared, consisting of $0.5 \mathrm{~mL}$ Tris- $\mathrm{HCl}$ Buffer (pH 8.2), $10 \mu \mathrm{L} 2 \mathrm{mM}$ pyrogallol, and $0.5 \mathrm{~mL}$ ddH20 and mixed with $8 \mu \mathrm{L}$ supernatant. The prepared test mixture was immediately analyzed at 325 and $420 \mathrm{~nm}$ against a blank solution (containing pyrogallol) at 3 min intervals in a spectrophotometer. The oxidation data for pyrogallol were taken every minute for 3 minutes and used to determine $100 \%$ auto-oxidation. The measured data are expressed as units per milligram of protein (1 unit is the amount of enzyme used to inhibit $50 \%$ of pyrogallol oxidation per minute $=y$ unit). SOD content was calculated by following equation:

$\mathrm{SOD}=(\mathrm{Y} \quad$ unit $) /($ Vol.enzyme extract $) \quad \times$ $($ Vol.extraction $) /($ Fresh weight $(\mathrm{FW})) \times \mathrm{df}$

To analysis hydrogen peroxide $\left(\mathrm{H}_{2} \mathrm{O}_{2}\right), 50 \mathrm{mg}$ fresh leaf was homogenized in $0.5 \mathrm{~mL} 0.1 \%$ TCA, centrifuged and 50 $\mu \mathrm{L}$ was used in the assay. Hydrogen peroxide $\left(\mathrm{H}_{2} \mathrm{O}_{2}\right)$ concentration was measured according to Jiang et al. (1990), based on the peroxide-mediated oxidation of $\mathrm{Fe}^{2+}$, followed by reaction of $\mathrm{Fe}^{3+}$, with xylenol orange. $\mathrm{H}_{2} \mathrm{O}_{2}$ content was calculated by following equation:

$$
\mathrm{H}_{2} \mathrm{O}_{2}=(1000 \times(\mathrm{A} 532-\mathrm{A} 600)) /(155 / \mathrm{FW} \times \mathrm{df})
$$

Malondialdehyde (MDA) content was assayed according to Hodges et al. (1999) with slight modifications. Fifty mg fresh weight (FW) of leaf was homogenized in 1 $\mathrm{mL}$ of TCA $0.1 \%$. After centrifugation, $0.5 \mathrm{~mL}$ of the supernatant reacted with thiobarbituric acid (TBA) to produce pinkish-red chromogen, thiobarbituric acidmalondialdehyde (TBA MDA). The solution heated in water bath at temperature of $95^{\circ} \mathrm{C}$ for 30 minutes, then cooled down in an icebox for 5 minutes. Then, centrifuged at $15.000 \mathrm{rpm}$ in $4^{\circ} \mathrm{C}$ for 20 minutes. The supernatant was measured at 450, 532, and $600 \mathrm{~nm}$ by using spectrophotometry. MDA content was calculated and expressed as nmol $\mathrm{g}^{-1} \mathrm{FW}$ tissue. MDA content was calculated by following equation:

$\mathrm{MDA}=6.452 / 6,42 \times[\mathrm{A} 523-\mathrm{A} 600]-0.559 \times \mathrm{A} 450 \times$ $($ Vol.extraction $) /($ Vol.test $) \times$ Fresh weight.

Anthocyanin content can be used as biomarker for different abiotic stress factors. Anthocyanin was assayed according to Lotkowska et al. (2015). $20 \mathrm{mg}$ of fresh weight of leaf (without midrib) then crushed using liquid nitrogen to become a fine powder, then homogenated with $1 \mathrm{~mL}$ buffer extraction (hydrochloric acid 37\%, 1-propanol, $\mathrm{ddH}_{2} \mathrm{O}$ ). The solution was incubated at $98^{\circ} \mathrm{C}$ for 3 minutes, and then incubated in room temperature for 120 minutes (in the dark condition). The solution was spun down at $25^{\circ} \mathrm{C}$ for 15 minutes with $13.000 \mathrm{rpm}$. The absorbance measurement was carried out with a wavelength $(\lambda)$ of 535 , 620, and $720 \mathrm{~nm}$. Anthocyanin content was calculated by following equation:

Anthocyanin $=(($ A535-0.25 $) \times$ A650 $) /($ Fresh weight $)$

\section{Data analysis}

The data were analyzed by Analysis of Variance (ANOVA) using SPSS software (version 22). The 
differences between means were compared by Duncan's test at $\mathrm{p}<0.05$. Correlation among parameters measured by the Pearson correlation test $(\mathrm{p}<0.05)$.

\section{RESULTS AND DISCUSSION}

The potential of magnetized seawater is evaluated in relation to the growth, physiological and biochemical responses of two rice cultivars IR 64 and Inpari 35 which have different characteristics. Inpari 35 is susceptible to salinity while IR 64 is tolerant to salinity treatment.

\section{Growth performance}

Magnetized seawater treatment can reduce the salinity of seawater from $10 \mathrm{dS} \mathrm{m}^{-1}$ to $7 \mathrm{dS} \mathrm{m}^{-1}$ in 3 magnetization cycles (Table 1). Decrease in salinity of seawater can reduce salinity stress in plants resulting in increased plant height growth in both IR 64 and Inpari 35 rice plants. Plant growth in treatment with salinity levels of $10 \mathrm{dS} \mathrm{m} \mathrm{m}^{-1}$ without magnetized water treatment was lower than that of the control. Salinity level and magnetized water treatment significantly affected plant height, fresh weight, and dry weight at 25 and 55 DAP (Table 2). The level of seawater salinity also affects plant height. Plant height, fresh weight and dry weight of rice plants in the magnetized water treatment (1,2 and 3 cycles treated with magnetic device) were higher than that of the control (without treated with magnetic device) both at salinity levels of 0 and $10 \mathrm{dS} \mathrm{m}^{-1}$. The effect of magnetized seawater treatment on plant growth is more visible in IR 64 rice plants. This relates to the character of IR 64 which is susceptible to salinity.

Treatment at a salinity level of $10 \mathrm{dS} \mathrm{\textrm {m } ^ { - 1 }}$ lead to a decrease in fresh weight and dry weight of plants IR 64 and 'Inpari35' at 25 and 55 DAP compared to control, while magnetized water treatment increased fresh and dry weight of plants. The more magnetization cycles, the higher the fresh and dry weight of the plant compared to the control. This is possible because the more the magnetization cycles, the longer the exposure time to the magnetic field, the higher the decrease in water salinity.

\section{Physiological responses}

Physiological responses were observed at 25 and 55 DAP included levels of chlorophyll a and chlorophyll b, relative water content (RWC), membrane stability index (MSI), and proline content. Increasing level of salinity has an effect on decreasing levels of chlorophyll a and chlorophyll b, but the magnetization of seawater can increase the levels of chlorophyll $a$ and chlorophyll $b$ in line with the increase of the cycle of magnetic treatment (Table 3). The combination of magnetized water and salinity level treatment affected the levels of chlorophyll a and chlorophyll b, RWC, and MSI at 25 and 55 DAP, proline content at 55 DAP. The combination of magnetized water and salinity level treatment had no effect on proline levels at the age of 25 DAP. The increase in salinity levels resulted in decreased levels of chlorophyll a, chlorophyll b, carotenoids, RWC, and increased MSI and proline, however, magnetized water treatment can increase levels of chlorophyll a and chlorophyll b, carotenoids, RWC, and decrease MSI and proline in line with the increase in the magnetized water treatment cycle. Membrane stability index increased in line with the increase in salinity levels at the age of 25 and 55 DAP. Magnetized water treatment was able to reduce MSI in IR 64 and Inpari 35. The highest membrane damage occurred at IR 64 at a salinity level of $10 \mathrm{dS} \mathrm{m}^{-1}$ without magnetized water (Table 4).

\section{Biochemical properties}

Treatment of $10 \mathrm{dS} \mathrm{m} \mathrm{m}^{-1}$ salinity without magnetized water showed the highest anthocyanin, $\mathrm{SOD}, \mathrm{H}_{2} \mathrm{O}_{2}$, and MDA, while the lowest levels of anthocyanin, superoxide dismutase (SOD), $\mathrm{H}_{2} \mathrm{O}_{2}$, and malondialdehyde (MDA) were found in 3 cycles of magnetized water treatment with a salinity of $0 \mathrm{dS} \mathrm{m}{ }^{-1}$. The interaction of magnetized water treatment and salinity level affects the levels of anthocyanin, $\mathrm{SOD}, \mathrm{H}_{2} \mathrm{O}_{2}$, and MDA in plants at 25 and 55 DAP. The higher the salinity was in line with the increase in anthocyanin levels, while the application of magnetized water treatment had an effect on plants to reduce anthocyanin levels at 25 and 55 DAP compared to the control (Table 5).

Increased levels of chlorophyll a, carotenoids, MSI, RWC and decreased levels of proline, SOD, $\mathrm{H}_{2} \mathrm{O}_{2}$, and MDA can increase the dry weight of rice plants IR 64 at 25 DAP. Dry weight in Inpari 35 is only positively correlated with proline at 55 DAS and is not significantly correlated with other parameters at 25 and 55 DAS. The dry weight of rice IR 64 has a higher correlation than that of Inpari 35. The highest dry weight of IR 64 rice was found in 3 cycles of magnetic water treatment with a salinity level of $0 \mathrm{dS} \mathrm{m}^{-}$ 1. Treatment of 3 magnetized water cycles with salinity levels of $0 \mathrm{dS} \mathrm{m}^{-1}$ showed that the increase in dry weight IR 64 at 25 DAP was correlated with increased levels of chlorophyll a, carotenoids, MSI and RWC, and decreased levels of proline, SOD, $\mathrm{H}_{2} \mathrm{O}_{2}$ and MDA. IR 64 is more sensitive to magnetized water treatment than Inpari 35 , as shown by the Pearson correlation results which show that dry weight correlation of IR 64 is higher compared to Inpari 35 (Table 6).

Table 1. Salinity level of seawater and conjugative water after being treated with magnetic device

\begin{tabular}{lcc}
\hline \multirow{2}{*}{ Magnetic treatment } & \multicolumn{2}{c}{ Salinity level $\left(\mathbf{d S ~ m}^{-\mathbf{1}}\right)^{*}$} \\
\cline { 2 - 3 } & Seawater & $\begin{array}{c}\text { conjugative seawater } \\
\text { and freshwater }\end{array}$ \\
\hline Without magnetic treatment & 52 & 10 \\
1 cycle & 51 & 9 \\
2 cycles & 50 & 8 \\
3 cycles & 49 & 7 \\
\hline
\end{tabular}

Note: *salinity level is measured using EC meter 
Table 2. Growth of rice IR 64 and Inpari 35 with salinity level and magnetized treatments

\begin{tabular}{|c|c|c|c|c|c|c|}
\hline \multirow{3}{*}{ Treatments } & \multicolumn{6}{|c|}{ Parameters } \\
\hline & \multicolumn{2}{|c|}{ Plant height $(\mathrm{cm})$} & \multicolumn{2}{|c|}{ Fresh weight (g) } & \multicolumn{2}{|c|}{ Dry weight (g) } \\
\hline & 25 DAP & 55 DAP & 25 DAP & 55 DAP & 25 DAP & 55 DAP \\
\hline Inpari 35 S0 M0 & $38.20^{\mathrm{de}}$ & $73.70^{\text {ef }}$ & $0.137^{\mathrm{de}}$ & $7.260^{\mathrm{hi}}$ & $0.020^{\mathrm{a}}$ & $0.260^{\mathrm{f}}$ \\
\hline Inpari $35 \mathrm{~S} 10 \mathrm{M} 0$ & $38.43^{\text {de }}$ & $69.20^{\mathrm{bb}}$ & $0.120^{\mathrm{abc}}$ & $5.220^{\mathrm{cd}}$ & $0.033^{\mathrm{bc}}$ & $0.173^{\mathrm{bc}}$ \\
\hline Inpari 35 S0 M1 & $40.80^{\mathrm{e}}$ & $79.37^{\mathrm{g}}$ & $0.137^{\mathrm{de}}$ & $7.710^{\mathrm{i}}$ & $0.030^{\mathrm{abcd}}$ & $0.290^{\mathrm{gh}}$ \\
\hline Inpari 35 S10 M1 & $38.23^{\mathrm{de}}$ & $74.33^{\text {ef }}$ & $0.123^{\text {abcd }}$ & $5.753^{\mathrm{de}}$ & $0.033^{\mathrm{bcd}}$ & $0.217^{\mathrm{e}}$ \\
\hline Inpari 35 S0 M2 & $42.20^{\mathrm{f}}$ & $83.63^{\mathrm{h}}$ & $0.140^{\mathrm{ef}}$ & $8.383^{\mathrm{g}}$ & $0.023^{\mathrm{ab}}$ & $0.360^{\mathrm{i}}$ \\
\hline Inpari 35 S10 M2 & $38.37^{\mathrm{d}}$ & $76.90^{\mathrm{fg}}$ & $0.117^{\mathrm{ab}}$ & $6.730^{\mathrm{gh}}$ & $0.027^{\mathrm{abc}}$ & $0.267^{\text {fg }}$ \\
\hline Inpari 35 S0 M3 & $42.23^{\mathrm{f}}$ & $88.43^{\mathrm{i}}$ & $0.153^{\mathrm{fg}}$ & $8.693^{\mathrm{g}}$ & $0.030^{\mathrm{abcd}}$ & $0.463^{\mathrm{j}}$ \\
\hline Inpari 35 S10 M3 & $42.00^{\mathrm{ef}}$ & $80.37^{\text {gh }}$ & $0.133^{\text {cde }}$ & $7.203^{\text {hi }}$ & $0.033^{\mathrm{bcd}}$ & $0.300^{\mathrm{h}}$ \\
\hline IR64 S0 M0 & $31.67^{\mathrm{c}}$ & $67.20^{c}$ & $0.110^{\mathrm{a}}$ & $5.687^{\mathrm{de}}$ & $0.030^{\mathrm{abcd}}$ & $0.217^{\mathrm{e}}$ \\
\hline IR64 S10 M0 & $22.03^{\mathrm{a}}$ & $49.33^{\mathrm{a}}$ & $0.110^{\mathrm{a}}$ & $3.080^{\mathrm{a}}$ & $0.020^{\mathrm{a}}$ & $0.097^{\mathrm{a}}$ \\
\hline IR64 S0 M1 & $33.00^{c}$ & $68.20^{\mathrm{cd}}$ & $0.113^{\mathrm{a}}$ & $6.090^{\mathrm{ef}}$ & $0.037^{\mathrm{cd}}$ & $0.253^{\mathrm{fg}}$ \\
\hline IR64 S10 M1 & $23.37^{\mathrm{ab}}$ & $58.27^{\mathrm{b}}$ & $0.113^{\mathrm{a}}$ & $3.483^{\mathrm{ab}}$ & $0.023^{\mathrm{ab}}$ & $0.153^{\mathrm{b}}$ \\
\hline IR64 S0 M2 & $32.97^{\mathrm{c}}$ & $69.03^{\text {cd }}$ & $0.130^{\text {bcde }}$ & $6.457^{\mathrm{fg}}$ & $0.033^{\mathrm{bcd}}$ & $0.297^{\mathrm{h}}$ \\
\hline IR64 S10 M2 & $26.00^{\mathrm{b}}$ & $59.03^{\mathrm{b}}$ & $0.117^{\mathrm{ab}}$ & $4.037^{\mathrm{b}}$ & $0.023^{\mathrm{ab}}$ & $0.187^{\mathrm{cd}}$ \\
\hline IR64 S0 M3 & $33.17^{\mathrm{c}}$ & $71.93^{\mathrm{cd}}$ & $0.157^{\mathrm{g}}$ & $6.937^{\mathrm{gh}}$ & $0.040^{\mathrm{d}}$ & $0.363^{\mathrm{i}}$ \\
\hline IR64 S10 M3 & $30.33^{c}$ & $60.97^{\mathrm{b}}$ & $0.123^{\mathrm{abcd}}$ & $4.814^{c}$ & $0.033^{\text {bcd }}$ & $0.213^{\mathrm{de}}$ \\
\hline
\end{tabular}

Note: Means within the column of each cultivar followed by different letters differ significantly at $p<0.05$ using Duncan's test. M0: without treated with magnetic device, M1: 1 cycle, M2:2 cycles, and M3: 3 cycles treated with magnetic device. S0: salinity level 0, S10: salinity level $10 \mathrm{dS} \mathrm{m}^{-1}$

Table 3. Photosynthetic pigment of rice IR 64 and Inpari 35 with salinity level and magnetized treatments

\begin{tabular}{|c|c|c|c|c|c|c|}
\hline \multirow{3}{*}{ Treatments } & \multicolumn{6}{|c|}{ Parameters } \\
\hline & \multicolumn{2}{|c|}{ Chlorophyll A (mg/g FW) } & \multicolumn{2}{|c|}{ Chlorophyll B (mg/g FW) } & \multicolumn{2}{|c|}{ Carotenoid (mg/g FW) } \\
\hline & 25 DAP & 55 DAP & 25 DAP & 55 DAP & 25 DAP & 55 DAP \\
\hline Inpari 35 S0 M0 & $1.630^{\mathrm{abcd}}$ & $1.567^{\mathrm{efg}}$ & $0.839^{\mathrm{abc}}$ & $2.392^{\mathrm{b}}$ & $0.656^{\mathrm{de}}$ & $0.633^{\mathrm{cd}}$ \\
\hline Inpari 35 S10 M0 & $1.454^{\mathrm{abc}}$ & $0.585^{\mathrm{a}}$ & $1.819^{\mathrm{e}}$ & $0.945^{\mathrm{a}}$ & $0.593^{\mathrm{c}}$ & $0.620^{\mathrm{c}}$ \\
\hline Inpari 35 S0 M1 & $1.809^{\mathrm{abcd}}$ & $1.894^{\mathrm{f}}$ & $1.353^{\text {cde }}$ & $2.557^{\mathrm{bc}}$ & $0.790^{\mathrm{f}}$ & $0.812^{\text {ef }}$ \\
\hline Inpari 35 S10 M1 & $1.692^{\mathrm{abcd}}$ & $0.682^{\mathrm{ab}}$ & $0.872^{\mathrm{abc}}$ & $0.970^{\mathrm{a}}$ & $0.624^{\mathrm{cd}}$ & $0.701^{\mathrm{d}}$ \\
\hline Inpari 35 S0 M2 & $1.973^{\mathrm{cd}}$ & $1.915^{\mathrm{f}}$ & $1.537^{\mathrm{de}}$ & $2.750^{\mathrm{bc}}$ & $0.869^{\mathrm{g}}$ & $0.873^{\mathrm{f}}$ \\
\hline Inpari 35 S10 M2 & $1.821^{\mathrm{abcd}}$ & $0.824^{\mathrm{abc}}$ & $1.205^{\mathrm{bcd}}$ & $0.983^{\mathrm{a}}$ & $0.682^{\mathrm{e}}$ & $0.777^{\mathrm{e}}$ \\
\hline Inpari 35 S0 M3 & $2.232^{\mathrm{d}}$ & $1.932^{\mathrm{f}}$ & $1.373^{\text {cde }}$ & $2.924^{\mathrm{c}}$ & $0.928^{\mathrm{h}}$ & $0.940^{\mathrm{g}}$ \\
\hline Inpari 35 S10 M3 & $1.860^{\mathrm{abcd}}$ & $0.833^{\mathrm{abc}}$ & $1.560^{\mathrm{de}}$ & $1.029^{\mathrm{a}}$ & $0.794^{\mathrm{f}}$ & $0.795^{\mathrm{e}}$ \\
\hline IR64 S0 M0 & $1.453^{\mathrm{abc}}$ & $0.787^{a b c}$ & $1.149^{\mathrm{abcd}}$ & $0.729^{\mathrm{a}}$ & $0.692^{\mathrm{e}}$ & $0.699^{\mathrm{d}}$ \\
\hline IR64 S10 M0 & $1.142^{\mathrm{a}}$ & $0.688^{a b}$ & $0.551^{\mathrm{a}}$ & $0.613^{\mathrm{a}}$ & $0.260^{\mathrm{a}}$ & $0.386^{\mathrm{a}}$ \\
\hline IR64 S0 M1 & $1.472^{\mathrm{abc}}$ & $1.235^{\text {cde }}$ & $0.688^{\mathrm{ab}}$ & $0.775^{\mathrm{a}}$ & $0.712^{\mathrm{e}}$ & $0.784^{\mathrm{e}}$ \\
\hline IR64 S10 M1 & $1.155^{\mathrm{a}}$ & $1.136^{\mathrm{bcd}}$ & $0.543^{\mathrm{a}}$ & $0.677^{a}$ & $0.484^{\mathrm{b}}$ & $0.536^{\mathrm{b}}$ \\
\hline IR64 S0 M2 & $1.646^{\mathrm{abcd}}$ & $1.647^{\mathrm{ef}}$ & $0.825^{\mathrm{abc}}$ & $0.838^{\mathrm{a}}$ & $0.808^{\mathrm{f}}$ & $0.870^{\mathrm{f}}$ \\
\hline IR64 S10 M2 & $1.241^{\mathrm{ab}}$ & $1.219^{\text {cde }}$ & $0.674^{\mathrm{ab}}$ & $0.681^{\mathrm{a}}$ & $0.525^{\mathrm{b}}$ & $0.616^{\mathrm{c}}$ \\
\hline IR64 S0 M3 & $1.735^{\mathrm{abcd}}$ & $1.370^{\mathrm{de}}$ & $1.001^{\mathrm{abcd}}$ & $0.942^{\mathrm{a}}$ & $0.904^{\mathrm{gh}}$ & $0.945^{\mathrm{h}}$ \\
\hline IR64 S10 M3 & $1.507^{\mathrm{abc}}$ & $1.511^{\mathrm{efg}}$ & $0.720^{\mathrm{ab}}$ & $0.750^{\mathrm{a}}$ & $0.702^{\mathrm{e}}$ & $0.671^{\mathrm{cd}}$ \\
\hline
\end{tabular}

Note: Means within the column of each cultivar followed by different letters differ significantly at $\mathrm{p}<0.05$ using Duncan's test. M0: without treated with magnetic device, M1: 1 cycle, M2:2 cycles, and M3: 3 cycles treated with magnetic device. S0: salinity level 0, S10: salinity level $10 \mathrm{dS} \mathrm{m}^{-1}$

Table 4. Physiological characters of rice IR 64 and Inpari 35 with salinity level and magnetized treatments

\begin{tabular}{|c|c|c|c|c|c|c|}
\hline \multirow{3}{*}{ Treatments } & \multicolumn{6}{|c|}{ Parameters } \\
\hline & \multicolumn{2}{|c|}{ Proline (ng/mol / FW) } & \multicolumn{2}{|c|}{ Relative Water Content (\%) } & \multicolumn{2}{|c|}{ Membrane Stability Index } \\
\hline & 25 DAP & 55 DAP & 25 DAP & 55 DAP & 25 DAP & 55 DAP \\
\hline Inpari S0 M0 & 0.457 & $0.539^{\mathrm{ab}}$ & $92.010^{\mathrm{bc}}$ & $93.930^{\mathrm{cd}}$ & $90.212^{\mathrm{a}}$ & $91.245^{\text {cde }}$ \\
\hline Inpari S10 M0 & 0.479 & $0.894^{\mathrm{ab}}$ & $87.446^{\mathrm{ab}}$ & $88.674^{\mathrm{bc}}$ & $93.143^{\mathrm{ab}}$ & $97.832^{\mathrm{cd}}$ \\
\hline Inpari S0 M1 & 0.452 & $0.472^{\mathrm{ab}}$ & $94.438^{\mathrm{bc}}$ & $95.073^{\mathrm{cd}}$ & $89.265^{a}$ & $89.265^{\mathrm{abc}}$ \\
\hline Inpari S10 M1 & 0.476 & $0.860^{\mathrm{ab}}$ & $88.041^{\mathrm{ab}}$ & $90.913^{\mathrm{cd}}$ & $93.043^{\mathrm{ab}}$ & $96.890^{\mathrm{fg}}$ \\
\hline Inpari S0 M2 & 0.424 & $0.461^{\mathrm{a}}$ & $96.748^{c}$ & $97.759^{\mathrm{d}}$ & $88.914^{\mathrm{a}}$ & $87.280^{\mathrm{abc}}$ \\
\hline Inpari S10 M2 & 0.471 & $0.534^{\mathrm{ab}}$ & $92.130^{\mathrm{bc}}$ & $91.255^{\mathrm{cd}}$ & $91.654^{\mathrm{ab}}$ & $95.309^{\text {efg }}$ \\
\hline Inpari S0 M3 & 0.409 & $0.447^{\mathrm{a}}$ & $97.226^{c}$ & $98.630^{\mathrm{d}}$ & $87.617^{a}$ & $85.662^{\mathrm{ab}}$ \\
\hline Inpari S10 M3 & 0.469 & $0.458^{\mathrm{a}}$ & $93.732^{\mathrm{bc}}$ & $94.816^{\mathrm{cd}}$ & $89.759^{\mathrm{a}}$ & $94.495^{\mathrm{def}}$ \\
\hline IR 64 S0 M0 & 0.454 & $0.603^{\mathrm{ab}}$ & $90.192^{\mathrm{bc}}$ & $91.433^{\mathrm{cd}}$ & $94.348^{\mathrm{ab}}$ & $91.189^{\text {cde }}$ \\
\hline IR 64 S10 M0 & 0.511 & $0.947^{\mathrm{b}}$ & $80.540^{\mathrm{a}}$ & $78.249^{a}$ & $97.249^{\mathrm{b}}$ & $99.314^{\mathrm{g}}$ \\
\hline IR 64 S0 M1 & 0.452 & $0.576^{\mathrm{ab}}$ & $91.679^{\mathrm{bc}}$ & $93.106^{\mathrm{cd}}$ & $92.819^{\mathrm{ab}}$ & $87.939^{\mathrm{abc}}$ \\
\hline IR 64 S10 M1 & 0.487 & $0.785^{\mathrm{ab}}$ & $87.384^{\mathrm{ab}}$ & $82.892^{\mathrm{ab}}$ & $93.552^{\mathrm{ab}}$ & $98.798^{\mathrm{fg}}$ \\
\hline IR 64 S0 M2 & 0.431 & $0.537^{\mathrm{ab}}$ & $93.915^{\mathrm{bc}}$ & $96.036^{\mathrm{cd}}$ & $90.668^{a}$ & $85.674^{\mathrm{ab}}$ \\
\hline IR 64 S 10 M2 & 0.484 & $0.603^{\mathrm{ab}}$ & $89.895^{\mathrm{bc}}$ & $89.454^{\mathrm{ab}}$ & $90.418^{a}$ & $96.970^{\mathrm{fg}}$ \\
\hline IR 64 S0 M3 & 0.413 & $0.433^{\mathrm{a}}$ & $94.013^{\mathrm{bc}}$ & $97.857^{\mathrm{d}}$ & $90.357^{\mathrm{a}}$ & $83.766^{\mathrm{a}}$ \\
\hline IR 64 S10 M3 & 0.480 & $0.000518^{\mathrm{ab}}$ & $90.384^{\mathrm{bc}}$ & $91.223^{\mathrm{cd}}$ & $88.794^{\mathrm{a}}$ & $93.385^{\text {def }}$ \\
\hline
\end{tabular}

Note: Means within the column of each cultivar followed by different letters differ significantly at $\mathrm{p}<0.05$ using Duncan's test. M0: without treated with magnetic device, M1: 1 cycle, M2:2 cycles and M3: 3 cycles treated with magnetic device. S0: salinity level 0, S10: salinity level $10 \mathrm{dS} \mathrm{m}^{-1}$ 
Table 5. Oxidative response of rice IR 64 and Inpari 35 with salinity level and magnetized treatments

\begin{tabular}{|c|c|c|c|c|c|c|c|c|}
\hline \multirow{3}{*}{ Treatments } & \multicolumn{8}{|c|}{ Parameters } \\
\hline & \multicolumn{2}{|c|}{ SOD $(\mathbf{U} / L)$} & \multicolumn{2}{|c|}{$\mathrm{H}_{2} \mathrm{O}_{2}(\mathrm{mg} / \mathrm{g} \mathrm{FW})$} & \multicolumn{2}{|c|}{ MDA (mg/g FW) } & \multicolumn{2}{|c|}{ Anthocyanin (mg/g FW) } \\
\hline & 25 DAP & 55 DAP & 25 DAP & 55 DAP & 25 DAP & 55 DAP & 25 DAP & 55 DAP \\
\hline Inpari S0 M0 & $0.012^{\mathrm{e}}$ & $0.013^{\text {def }}$ & $0.013^{\text {def }}$ & $0.012^{\mathrm{e}}$ & $0.013^{\text {def }}$ & $0.013^{\text {def }}$ & $3.863^{\text {bcd }}$ & $3.863^{\mathrm{bcd}}$ \\
\hline Inpari S10 M0 & $0.014^{\mathrm{f}}$ & $0.014^{\mathrm{fg}}$ & $0.014^{\mathrm{fg}}$ & $0.014^{\mathrm{f}}$ & $0.014^{\text {fg }}$ & $0.014^{\mathrm{fg}}$ & $3.954^{\mathrm{bcd}}$ & $3.954^{\mathrm{bcd}}$ \\
\hline Inpari S0 M1 & $0.008^{\mathrm{abc}}$ & $0.012^{\text {cde }}$ & $0.012^{\text {cde }}$ & $0.008^{\mathrm{abc}}$ & $0.012^{\text {cde }}$ & $0.012^{\text {cde }}$ & $2.829^{\mathrm{abc}}$ & $2.829^{\mathrm{abc}}$ \\
\hline Inpari S10 M1 & $0.012^{\text {de }}$ & $0.014^{\text {efg }}$ & $0.014^{\mathrm{efg}}$ & $0.012^{\text {de }}$ & $0.014^{\text {efg }}$ & $0.014^{\mathrm{efg}}$ & $3.521^{\mathrm{abcd}}$ & $3.521^{\mathrm{abcd}}$ \\
\hline Inpari S0 M2 & $0.007^{\mathrm{ab}}$ & $0.011^{\mathrm{cd}}$ & $0.011^{\mathrm{cd}}$ & $0.007^{\mathrm{ab}}$ & $0.011^{\mathrm{cd}}$ & $0.011^{\mathrm{cd}}$ & $2.508^{\mathrm{ab}}$ & $2.508^{\mathrm{ab}}$ \\
\hline Inpari S10 M2 & $0.010^{\text {cde }}$ & $0.012^{\text {cde }}$ & $0.012^{\text {cde }}$ & $0.010^{\text {cde }}$ & $0.012^{\text {cde }}$ & $0.012^{\text {cde }}$ & $3.350^{\mathrm{abcd}}$ & $3.350^{\mathrm{abcd}}$ \\
\hline Inpari S0 M3 & $0.006^{\mathrm{a}}$ & $0.011^{\mathrm{cd}}$ & $0.011^{\mathrm{cd}}$ & $0.006^{\mathrm{a}}$ & $0.011^{\mathrm{cd}}$ & $0.011^{\mathrm{cd}}$ & $2.346^{\mathrm{ab}}$ & $2.346^{\mathrm{ab}}$ \\
\hline Inpari S10 M3 & $0.009^{\mathrm{bc}}$ & $0.012^{\text {cde }}$ & $0.012^{\text {cde }}$ & $0.009^{\mathrm{bc}}$ & $0.012^{\text {cde }}$ & $0.012^{\text {cde }}$ & $3.304^{\mathrm{abcd}}$ & $3.304^{\mathrm{abcd}}$ \\
\hline IR 64 S0 M0 & $0.011^{\mathrm{de}}$ & $0.012^{\text {cde }}$ & $0.012^{\text {cde }}$ & $0.011^{\mathrm{de}}$ & $0.012^{\text {cde }}$ & $0.012^{\text {cde }}$ & $2.463^{\mathrm{ab}}$ & $2.463^{\mathrm{ab}}$ \\
\hline IR 64 S10 M0 & $0.020^{\mathrm{h}}$ & $0.020^{\mathrm{g}}$ & $0.020^{\mathrm{g}}$ & $0.020^{\mathrm{h}}$ & $0.020^{\mathrm{g}}$ & $0.020^{\mathrm{g}}$ & $5.225^{\mathrm{d}}$ & $5.225^{\mathrm{d}}$ \\
\hline IR 64 S0 M1 & $0.010^{\text {cd }}$ & $0.010^{\mathrm{bc}}$ & $0.010^{\mathrm{bc}}$ & $0.010^{\text {cd }}$ & $0.010^{\mathrm{bc}}$ & $0.010^{\mathrm{bc}}$ & $2.158^{\mathrm{ab}}$ & $2.158^{\mathrm{ab}}$ \\
\hline IR 64 S10 M1 & $5.033^{\mathrm{cd}}$ & $5.033^{\mathrm{cd}}$ & $0.018^{\mathrm{h}}$ & $0.015^{\mathrm{f}}$ & $0.015^{\mathrm{f}}$ & $0.013^{\text {fgh }}$ & $5.033^{\mathrm{cd}}$ & $5.033^{\mathrm{cd}}$ \\
\hline IR 64 S0 M2 & $1.946^{\mathrm{ab}}$ & $1.946^{\mathrm{ab}}$ & $0.008^{\mathrm{abc}}$ & $0.008^{\mathrm{ab}}$ & $0.008^{\mathrm{ab}}$ & $0.008^{\mathrm{a}}$ & $1.946^{\mathrm{ab}}$ & $1.946^{\mathrm{ab}}$ \\
\hline IR $64 \mathrm{~S} 10 \mathrm{M} 2$ & $4.913^{\text {cd }}$ & $4.913^{\text {cd }}$ & $0.015^{\mathrm{f}}$ & $0.012^{\mathrm{de}}$ & $0.012^{\text {de }}$ & $0.012^{\text {defg }}$ & $4.913^{\mathrm{cd}}$ & $4.913^{\mathrm{cd}}$ \\
\hline IR 64 S0 M3 & $1.242^{\mathrm{a}}$ & $1.242^{\mathrm{a}}$ & $0.007^{\mathrm{ab}}$ & $0.007^{\mathrm{a}}$ & $0.007^{\mathrm{a}}$ & $0.006^{\mathrm{a}}$ & $1.242^{\mathrm{a}}$ & $1.242^{\mathrm{a}}$ \\
\hline IR 64 S10 M3 & $4.071^{\mathrm{bcd}}$ & $4.071^{\mathrm{bcd}}$ & $0.012^{\text {de }}$ & $0.011^{\text {cde }}$ & $0.011^{\text {cde }}$ & $0.010^{\mathrm{bc}}$ & $4.071^{\mathrm{bcd}}$ & $4.071^{\mathrm{bcd}}$ \\
\hline
\end{tabular}

Note: Means within the column of each cultivar followed by different letters differ significantly at $\mathrm{p}<0.05$ using Duncan's test. M0: without treated with magnetic device, M1: 1 cycle, M2:2 cycles and M3: 3 cycles treated with magnetic device. S0: salinity level 0, S10: salinity level $10 \mathrm{dS} \mathrm{m}^{-1}$

Table 6. Correlation between dry weight with physiological and biochemical responses of rice IR 64 and Inpari 35 at 25 and 55 DAP

\begin{tabular}{|c|c|c|c|c|}
\hline \multirow{2}{*}{ Physiological responses } & \multicolumn{2}{|c|}{ Dry weight 25 DAP } & \multicolumn{2}{|c|}{ Dry weight 55 DAP } \\
\hline & IR 64 & Inpari 35 & IR 64 & Inpari 35 \\
\hline Chlorophyll a & $0.424 *$ & $-0.218^{\mathrm{ns}}$ & $0.358^{\mathrm{ns}}$ & $-0.148^{\mathrm{ns}}$ \\
\hline Chlorophyll b & $0.264^{\mathrm{ns}}$ & $0.248^{\mathrm{ns}}$ & $0.661 * *$ & $0.096^{\mathrm{ns}}$ \\
\hline Carotenoid & $0.769 * *$ & $-0.080^{\mathrm{ns}}$ & $0.769 * *$ & $-0.278^{\mathrm{ns}}$ \\
\hline MSI & $0.506 * *$ & $0.138^{\mathrm{ns}}$ & $0.717 * *$ & $-0.098^{\mathrm{ns}}$ \\
\hline RWC & $0.573 * *$ & $-0.379^{\text {ns }}$ & $0.518 * *$ & $-0.158^{\mathrm{ns}}$ \\
\hline Proline & $-0.551 * *$ & $0.006^{\mathrm{ns}}$ & $-0.369^{\mathrm{ns}}$ & $0.427 *$ \\
\hline \multirow{2}{*}{ Biochemical responses } & \multicolumn{2}{|c|}{ Dry weight 25 DAP } & \multicolumn{2}{|c|}{ Dry weight 55 DAP } \\
\hline & IR 64 & Inpari 35 & IR 64 & Inpari 35 \\
\hline Anthocyanin & $-0.568^{\mathrm{ts}}$ & $-0.289^{\mathrm{ts}}$ & $-0.573 * *$ & $0.054^{\mathrm{ts}}$ \\
\hline SOD & $-0.643^{* *}$ & $-0.238^{\mathrm{ts}}$ & $-0.682 * *$ & $-0.089^{\mathrm{ts}}$ \\
\hline $\mathrm{H}_{2} \mathrm{O}_{2}$ & $-0.728^{* *}$ & $-0.072^{\mathrm{ts}}$ & $-0.611 * *$ & $0.018^{\mathrm{ts}}$ \\
\hline MDA & $-0.729^{* *}$ & $-0.043^{\mathrm{ts}}$ & $-0.701 * *$ & $0.040^{\text {ts }}$ \\
\hline
\end{tabular}

Note: Pearson correlation test *: significant on $\mathrm{p}<0.05$; **: significant on $\mathrm{p}<0.01$; ts: not significant. DAP: Day After Planting

\section{Discussion}

The effect of magnetized seawater treatment on plant growth is more visible to increase the growth of IR 64 rice plants (Fig 1). This relates to the character of IR 64 which is susceptible to salinity. Application of magnetized seawater can reduce the salinity of seawater from $10 \mathrm{dS} \mathrm{m}^{-1}$ to $7 \mathrm{dS} \mathrm{m}^{-1}$ in 3 magnetization cycles (Table 1). Decreasing water salinity can reduce salinity stress in plants due to increase plant height growth of both IR 64 and Inpari 35 rice plants. Plant growth in treatment with a salinity level of $10 \mathrm{dS} \mathrm{m}^{-1}$ without magnetized water treatment was lower than control (Table 2). This is because of an increase of the concentration of $\mathrm{Na}^{+}$ions in the soil during salinity stress. $\mathrm{Na}^{+}$ions will compete $\mathrm{K}^{+}$ions because both of them have the same transport and transporter mechanisms, resulting in a decrease in absorption of $\mathrm{K}^{+}$ions which leads to an imbalance of ions in the cell and causes growth inhibition in plants, decreased osmotic regulation capacity, turgor, reduced the number of tillers, dry weight, number of leaves, inhibited leaf initiation and expansion (Amirjani 2010; Gupta 2014). In line with Mahmood et al (2009), the decrease of dry weight and fresh weight occurred on the $55^{\text {th }}$ day after planting by $61 \%$ at a salinity of $10.5 \mathrm{dS} \mathrm{m}^{-1}$ compared to control. In addition, the decrease of the number of tillers about $29 \%$ at a salinity level of $6-12 \mathrm{dS}$ $\mathrm{m}^{-1}$ for 2 weeks can reduce biomass by $26 \%$ and $31 \%$ of total biomass at the end of vegetative growth (Munns and Tester 2008). 


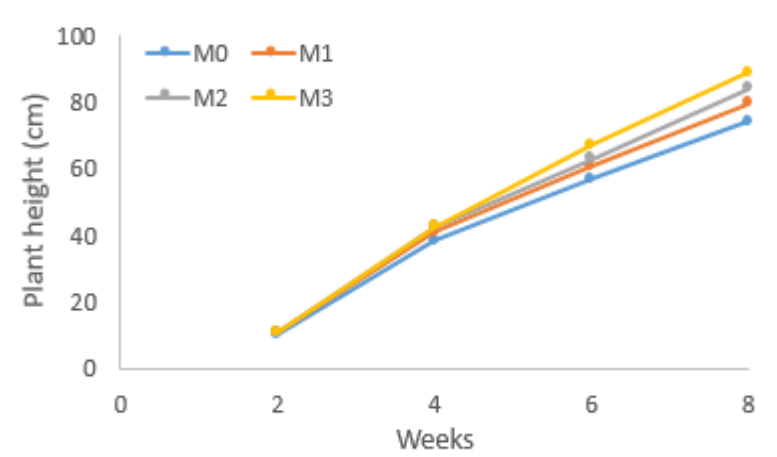

A

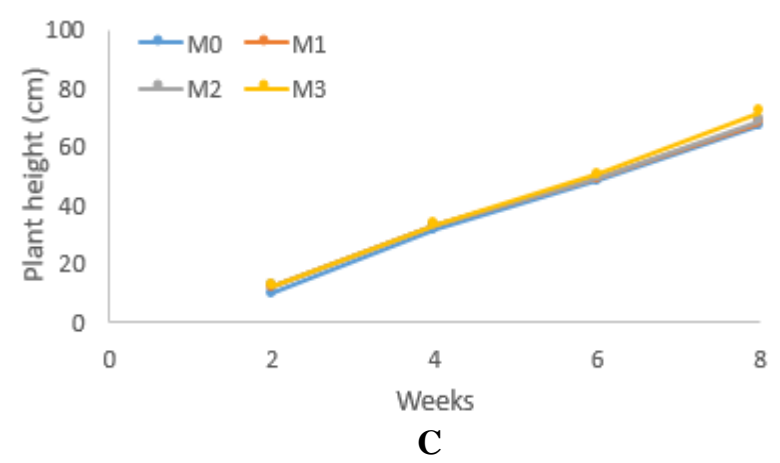

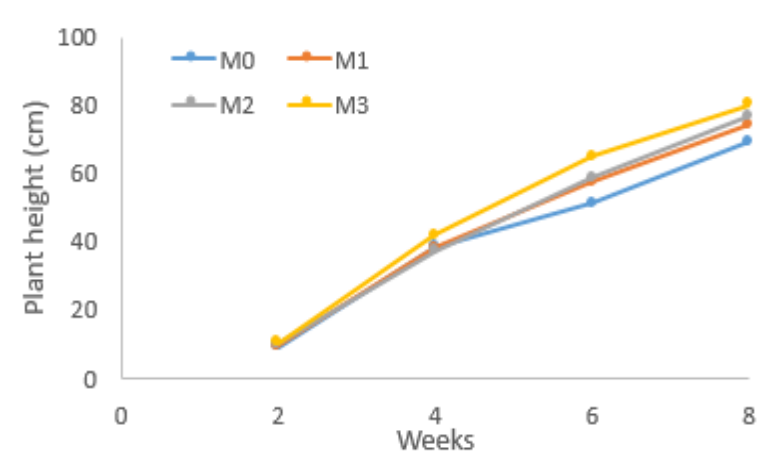

B

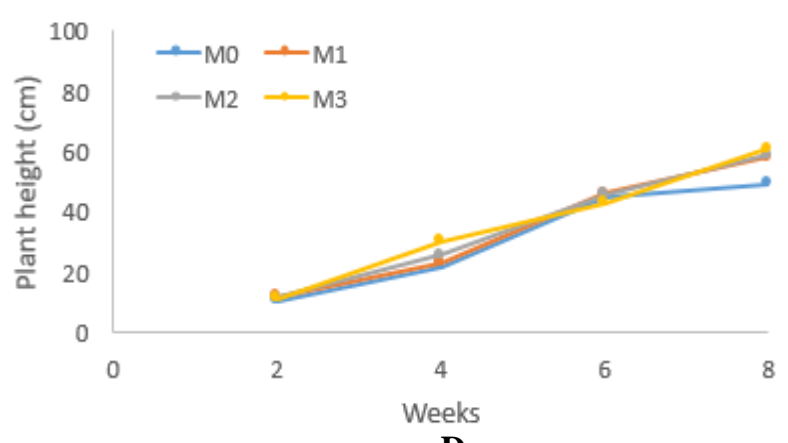

D

Figure 1. Plant growth of rice IR 64 and Inpari 35 with salinity level and magnetized treatments. A 'IR64' at salinity level 0. B. 'IR64' at salinity $10 \mathrm{dS} \mathrm{m}^{-1}$, C. Inpari 35 at salinity level 0 . D. Inpari 35 at salinity $10 \mathrm{dS} \mathrm{m}^{-1}$. M. Magnetized seawater treatment (M0: without treated with magnetic device, M1: 1 cycle, M2:2 cycles, and M3: 3 cycles treated with magnetic device) and salinity level 0: freshwater and salinity level $10 \mathrm{dS} \mathrm{m}^{-1}$ : conjugative seawater with freshwater

Plants irrigated with magnetized water can easily absorb nutrients from the soil and promote vegetative growth (Sadeghipour and Aghaei 2013; Nasser 2008). Therefore the plants are supplied with sufficient nutrients for proper growth stage and metabolic processes, which help to improve the rates of growth performances. This finding is consistent with the research of Maheswari and Grewal (2009) which showed that an increase in plant height is also reflected in an increase of biomass with magnetized water treatment. In this study, it was shown the increase of plant fresh weight and dry weight (Table 2). Treatment at a salinity level of $10 \mathrm{dS} \mathrm{m}^{-1}$ leads to a decrease of fresh weight and dry weight of IR 64 and 'Inpari35' at 25 and 55 DAP compared to control, while magnetized water treatment increased fresh and dry weight of plants. The more magnetization cycles, the higher the fresh and dry weight values of the plant compared to the control. This is possible because the more the magnetization cycles, the longer the exposure time to the magnetic field, the higher the decrease in water salinity. According to Sadeghipour and Aghaei (2013), magnetized water increased cowpea biomass, stomatal conductance, and water use efficiency. Magnetic treatment affects the biochemical and physical reaction of water that affects plant biochemical reactions, including enzymatic activity. Magnetic treatment increased the nutrient and water uptake and cell permeability resulting in an increase in plant biomass (Nasser 2008).
Furthermore, giving magnetized water significantly increases cell metabolism and mitotic cell division, thereby accelerating the growth rate in plants and encouraging vegetative growth faster than normal. Some scientists have found that the magnetic field (MF) enhances seed germination by changing the biochemical processes through stimulating activity of proteins and enzymes (Maffei 2014; Phirke et al. 1996). In fact, MF interacts with internal electric field of biological systems through its resonating behavior. Living cells possess electric charges exerted by ions or free radicals, which act as endogenous magnets and have been involved in the biochemical processes. Thus, external MF treatment increases ion uptake and therefore improves nutrition value (Martinez et al. 2017). Others studies stated that the MF interacts with ion current in the membrane of the embryo cell. This interaction changes the ion concentration and osmotic pressure on both sides of the membrane, thereby changing the relationship between water and seeds (Reina and Pascual 2001).

Carotenoid levels increased in 'IR 64,' but those were not significantly different from the control in Inpari 35. Abobatta (2015) reported that application magnetic water can increase rice growth, photosynthetic pigment content, organic components and total protein in rice. Cell metabolism and mitotic cell division meristematic significantly induced by magnetized water treatment. The increase in photosynthetic pigments occurred in chlorophyll a, b and total chlorophyll treated with magnetic 
water, indicating that there was an improvement in ion mobility and ion absorption after being treated with magnetic water.

The combination of magnetized water and salinity levels treatment affected chlorophyll $\mathrm{a}$ and $\mathrm{b}$ levels at the 25 and 55 DAP on both IR 64 and Inpari 35. The lowest chlorophyll content was found in the treatment with a salinity level of $10 \mathrm{dS} \mathrm{m}$. There was a decrease in chlorophyll levels at IR 64 and Inpari 35 at a salinity level of $10 \mathrm{dS} \mathrm{m}^{-1}$ compared to control. Even though Inpari 35 is a tolerant saline cultivar, the treatment has decreased chlorophyll content. This is possible because the tolerance of Inpari 35 was expressed at the seedling phase (Ministry of Agriculture 2014), and the treatment in this study was carried out at the age of 14 to 55 days after planting, resulting in salinity stress with a salinity level of $10 \mathrm{dS} \mathrm{m}^{-1}$. Chlorophyll is a photosynthetic pigment, an indicator of plant health and is responsible for stress response mechanisms. Application of magnetized water to plant can increase chlorophyll levels due to paramagnetic properties of chloroplasts which can be affected by magnetic treatment by increasing ion mobility and ion absorption which increases photostimulation and growth. Magnetic fields have the ability to alter the physical and chemical composition of water, increasing the content of photosynthetic pigments in rice plants (Dhawi and Alkhayri 2009). In line with Tian et al (1989) magnetized water has the potential to increase the assimilator pigment level resulting in increased of chlorophyll levels in rice plants. Magnetized water increases chlorophyll and carotenoid levels in leaves, which may be caused by proline and $\mathrm{GA}_{3}$, which are triggered by the accumulation of $\mathrm{Mg}^{2+}$ for chlorophyll synthesis (Radhakrishnan 2019) and $\mathrm{K}^{+}$to increase the number of chloroplasts (Reina and Pascual 2001).

Salinity stress causes osmotic differences. The water potential of leaves decreases and results in a decrease in the value of the relative water content (RWC) which leads to the closing stomata and limiting $\mathrm{CO}_{2}$ assimilation resulting in a decrease in the rate of photosynthesis (Amirjani 2010). Magnetic energy could enhance the physical and/or chemical properties of soil and water quality. The exposure of water to a magnetic field results in alterations of its basic properties such as ionic strength, $\mathrm{pH}$, and surface tension force, providing greater movement capacity by intensifying the internal vibration of water molecules, which improve the polarizing effect, resulting in an increase of water uptake into the cell (Tai et al. 2008). Cultivars with low cell membrane damage were relatively more tolerant against salinity stress than cultivars with higher intensity of cell damage (Liu and Huang 2000; Arvin and Donnelly 2008). According to Rana et al (2011), the intensity of cell membrane damage $<40 \%$ is categorized as tolerant. The main constituents of the cell membrane are phospholipids and proteins, which function not only to protect cells and organelles in cells, but also to support cell function. Cell membrane permeability is increased and cellular function is impaired. The genotype which has a low percentage of damage under high-temperature stress conditions indicates a relatively stable cell membrane, and it can protect the cellular functions (Handayani et al 2013). Increase in salinity causes increase in membrane stability index (MSI), which corresponds to a decrease in RWC in plants (Jamil et al. 2012). By lowering proline levels, magnetized water treatment can mitigate the effects of salinity stress. Proline also contributes to the stabilization of sub-cellular structures (membranes and proteins) and induces genes responsive to salinity stress. Proline levels increase with the increasing severity of salinity stress as a defense response to salinity stress (Rudolph et al. 1986; Yancey 1994; Carolli et al. 2011).

The magnetic field has a potential effect on the antioxidant system of the cells, and MF is involved in antioxidant-modulated response in the apoplast, causing tight control of the redox status disturbance (Cakmak et al. 2012). The beneficial effect of a magnetic field on lettuce plant growth may be due to maintaining an equilibrium between ROS production and scavenging (Latef et al. 2020). Compared to controls, magnetized water treatment can reduce levels of anthocyanin, $\mathrm{H}_{2} \mathrm{O}_{2}$, malondialdehyde (MDA), and superoxide dismutase (SOD). This is also consistent with the findings of Hasan et al. (2020), that providing magnetized water reduces levels of MDA, and $\mathrm{H}_{2} \mathrm{O}_{2}$ compared to controls. Magnetic treatment can be used to mitigate stress caused by the environment. The reduction in $\mathrm{H}_{2} \mathrm{O}_{2}$ and $\mathrm{O}_{2}$ levels in magnetized water treatment confirms that the magnetic field can control the production of ROS (Latef et al. 2020).

\section{ACKNOWLEDGEMENTS}

This research was supported by the Research Directory of Universitas Gadjah Mada, Yogyakarta, Indonesia through Final Project Recognition Programs (RTA). Letter Task No. 2488/UN1.P.III/DIT-LIT/PT/2020.

\section{REFERENCES}

Abobatta FW. 2015. Growth and Fruiting of Valencia Orange Trees. Lambert Academic Publishing, Sunnyvale.

Abobatta FW. 2019. Overview of role of magnetizing treated water in agricultural sector development. Adv Agric-Tech Plant Sci 2 (1): 1-7.

Ahanger MA, Agarwal RM. 2017. Salinity stress-induced alterations in antioxidant metabolism and nitrogen assimilation in wheat (Triticum aestivum L.) as influenced by potassium supplementation. Plant Physiol Biochem 115: 449-460. DOI: 10.1016/j.plaphy.2017.04.017

Alikamanoglu S, Sen A. 2011. Stimulation of growth and some biochemical parameters by magnetic fields in Wheat (Triticum aestivum L.) tissue cultures. Afr J Biotechnol 10 (53): 10957-10963. DOI: $10.5897 / \mathrm{AJB} 11.1479$

Ali Y, Samaneh R, Kavakebian F. 2014. Application of magnetic water technology in farming and agriculture development: A Review of Recent Advances. Curr World Environ 9 (3): 695-703. DOI: 10.12944/CWE.9.3.18

Amirjani RM. 2010. Effect of $\mathrm{NaCl}$ on some physiological parameters of rice. EJBS 3 (1): 6-16.

Arvin MJ, Donnelly DJ. 2008. Screening potato cultivars and wild species to abiotic stresses using an electrolyte leakage bioassay. J Agric Sci Technol 10: 33-42.

Atzori G, Mancuso S, Masi E. 2019. Seawater potential use in soilless culture: A Review. Sci Hortic 249: 199-207. DOI: 10.1016/j.scienta.2019.01.035 
Bahiyah A, Wirasatriya A, Marwoto J, Handoyo G. 2019. Study of seasonal variation of sea surface salinity in java sea and its surrounding seas using SMAP satellite. IOP Conf Earth Environ Sci 246: 1-12. DOI: $10.1088 / 1755-1315 / 246 / 1 / 012043$

Brinkman R, Singh VP. 1982. Rapid Reclamation of Brackish Water Fishponds in Acid Sulfate Soils. ILRI. Publ, Wageningen. Netherlands

Bates LS, Waldran RP, Teare ID. 1973. Rapid determination of free proline for water-stress studies. Plant Soil 39: 205.-207. DOI: 10.1007/BF00018060

Carolli P, Annunziata G, Pontercorvo GM, Fuggi A, Woodrow P. 2011. Salinity stress and salt tolerance, abiotic stress in plant - mechanism and adaptations. InTech 35 (2): 20-38. DOI: 10.5772/22331

Cakmak T, Çakmak ZE, Dumlupınar R, Tekinay T. 2012. Analysis of apoplastic and symplastic antioxidant system in shallot leaves: Impacts of weak static electric and magnetic field. J Plant Physiol 169: 1066-1073. DOI: 10.1016/j.jplph.2012.03.011

Dhawi F. 2013. Why magnetic fields are used to enhance a plant's growth and productivity?. Ann Res Rev Biol 4 (6): 886-896. DOI: 10.9734/ARRB/2014/5983

Dhawi F, Al-Khayri J. 2009. Magnetic fields induce changes in photosynthetic pigments date palm (Phoenix dactylifera $\mathrm{L}$.) seedlings. Agric J 3: 1-5. DOI: 10.2174/1874331500903010001

Handayani T, Basunanda P, Murti HR, Sofiari E. 2013. Cell membrane stability assay and chlorophyll content measurement to evaluate heat stress tolerance on potato. J Hortic 23 (1): 28-35. DOI 10.21082/jhort.v23n1.2013.p28-35

Hamuna B, Paulangan YP, Dimara L. 2018. Kajian suhu permukaan laut mengunakan data satelit Aqua-MODIS di perairan Jayapura, Papua. Depik 16 (1): 35-43. [Indonesian]

Hodges D, DeLong J, Forney C. Prange RK. 1999. Improving the thiobarbituric acid-reactive-substances assay for estimating lipid peroxidation in plant tissues containing anthocyanin and other interfering compounds. Planta 207: 604-611. DOI $10.1007 / \mathrm{s} 004250050524$

IWCA. 2018. Water Resource and Consumption. https://sites.google.com/site/isat380eindonesia/project-definition.

Jiang ZY, Woollard AC, Wolff SP. 1990. Hydrogen peroxide production during experimental protein glycation. FEBS Lett 268 (1): 69-71. DOI: $10.1016 / 0014-5793(90) 80974-n$

Latef AAHA, Dawood AFM, Hassanpour H, Rezayian M, Younes NA 2020. Impact of the static magnetic field on growth, pigments, osmolytes, nitric oxide, hydrogen sulfide, phenylalanine ammonialyase activity, antioxidant defense system, and yield in lettuce. Biology 9 (172): 1-18. DOI: 10.3390/biology9070172

Li J, Gao Y, Zhang X, Tian P, Li-Juan, Tian Y. 2019. Comprehensive comparison of different saline water irrigation strategies for tomato production: Soil properties, fruit yield and fruit quality. Agric Water Manag 213: 521-533. DOI: 10.1016/j.agwat.2018.11.003

Liu X, Zhu H, Wang Lu, Bi S, Zhang Z, Meng S, Zhang Y, Wang H, Song C, Ma F. 2019. The effect of magnetic treatment on nitrogen absorption and distribution in seedling of Populus $\times$ euramericana 'Neva' under $\mathrm{NaCl}$ stress. Sci Rep 9 (1): 10025. DOI: 10.1038/s41598-019-45719-6

Liu X, Huang B. 2000. Heat stress injury in relation to membrane lipid peroxidation in creeping bentgrass. Crop Sci 40: 503-510. DOI 10.2135/cropsci2000.402503x

Lotkowska EM, Tohge T, Fernie RA, Xue P-G, Balazadeh S, Roeber MB 2015. The Arabidopsis transcription factor MYB112 promotes anthocyanin formation during salinity and under high light stress Plant Physiol 169 (3): 1862-80. DOI: 10.1104/pp.15.00605

Lugojan C, Ciulca S. 2011. Evaluation of relative water content in winter wheat. J Hortic Fores Biotechnol 15: 173-177.

Maffei ME. 2014. Magnetic field effects on plant growth, development, and evolution. Front Plant Sci 5: 445. DOI: 10.3389/fpls.2014.00445

Maheswari BL, Grewal HS. 2009. Magnetic treatment of irrigation water: its effect on vegetable crop yield and water productivity. Agric Water Manag 96 (8): 1229-1236. DOI: 10.1016/j.agwat.2009.03.016
Mahmood A, Latif T, Khan, MA. 2009. Effect of salinity on growth, yield and yield components in basmati rice germplasm. Pak J Bot 41: 30353045 .

Martinez E, Florez M, Carbonell M. 2017. Stimulatory effect of the magnetic treatment on the germination of cereal seeds. Int $\mathrm{J}$ Environ Agric Biotechnol 2: 375-381. DOI: 10.22161/ijeab/2.1.47

Marklund S, Marklund, G. 1974. Involvement of the superoxide anion radical in the autoxidation of pyrogallol and a convenient assay for superoxide dismutase. Eur J Biochem 47: 469-474. DOI: 10.1111/j.1432-1033.1974.tb03714.x

Ministry of Agriculture. 2014. Rice production 2014-2018. https://www.pertanian.go.id/ home/?show=page\&act=view\&id=61

Munns R, Tester M. 2008. Mechanisms of salinity tolerance. Ann Rev Plant Biol 59: 651-681. DOI: 10.1146/annurev.arplant.59.032607.092911

Nasser SH. 2008. The effect of magnetic water on growth of chickpea seeds. Eng Tech 26 (9): 4-33.

Phirke P, Kubde A, Umbarkar S. 1996. The influence of magnetic field on plant growth. Seed Sci Technol 24: 375-392.

Prayoga MKN, Rostini MR, Setiawati T, Simarmata S, Stoeber K, Adinata. 2018. Preferensi petani terhadap keragaan padi (Oryza sativa) unggul untuklahan sawah di wilayah Pangandaran dan Cilacap. J Kultivasi 17 (1): 523-541. [Indonesian]

Radhakrishnan R. 2019. Magnetic field regulation, plant function, growth, and enhance tolerance against environmental stress. Physiol Mol Biol Plants 25 (5): 1107-1119. DOI: 10.1007/s12298-019-00699-9

Rana RM, Khan SH, Ali Z, Khan AI, Khan IA. 2011. Elucidation of thermotolerance diversity in cotton (Gossypium hirsutum L.) using physio-molecular approaches. Genet Mol Res 10 (2): 1156-1167. DOI: $10.4238 / \mathrm{vol10}-2 \mathrm{gmr} 1180$

Reina FG, Pascual LA. 2001. Influence of a stationary magnetic field on water relations in lettuce seeds. Part I: Theoretical considerations. Bioelectromagnetics 22: 589-595. DOI: $10.1002 / \mathrm{bem} .88$

Rudolph AS, Crowe JH, Crowe LM. 1986. Effects of three stabilizing agents: Proline, betaine, and trehalose on membrane phospholipids. Arch Biochem Biophys 245: 134-143. DOI: 10.1016/00039861(86)90197-9

Sadeghipour O, Aghaei P. 2013. Improving the growth of cowpea (Vigna unguiculata L.Walp.) by magnetized water. J Bio Env Sci 3 (1): 37 43.

Sitinjak H, Idwar. 2015. Respon berbagai varietas padi sawah (Oryza sativa L.) yang ditanam dengan pendekatan teknik budidaya jajar legowo dan sistem tegel. JOM Faperta 2 (2): 1-15. [Indonesian]

Suprihatno B, Daradjat AA, Satoto AE, Baehaki, Widiarta E, Setyono A. 2009. Deskripsi Kultivar Padi. Indonesian Center for Rice Research (ICRC), Indonesia. [Indonesian]

Swapna S, Korukkanvilakath SS. 2017. Screening for osmotic stress responses in rice varieties under drought conditions. Rice Sci 24 (5): 253-263. DOI: 10.1016/j.rsci.2017.04.004

Tai CY, Wu CK, Chang MC. 2008. Effects of magnetic field on the crystallization of $\mathrm{CaCO} 3$ using permanent magnets. Chem Eng Sci 63: 5606-5612. DOI: $10.1016 /$ j.ces.2008.08.004

Taslim H, Partohardono, Djunainah. 2010. Rice Field Farming. Food Crops Research and Development Center. Bogor Indonesia.

Tian WX, Kuang YL, Mei ZP. 1989. Effect of magnetic water on seed germination, seedling growth and grain yield of rice. J Jilin Agric Univ 11 (4): 11-16.

Yancey PH. 1994. Compatible and counteracting solutes. In: Strange K (ed) Cellular and molecular physiology of cell volume regulation. CRC Press, Boca Raton.

Yermiyahu U, Tal A, Ben-Gal A, Bar-Tal A, Tarchitzky J, Lahav O. 2007. Rethinking desalinated water quality and agriculture. Science 318 (80): 920-921. DOI: 10.1126/science.1146339

Yoshida S, Forno DA, Cock JH, Gomez KA. 1976. Laboratory Manual for Physiological Studies of Rice. 3rd ed. The International Rice Research Institute. Los Banos, Philippines. 